To cite: CC Ngang 'Systems problem and a pragmatic insight into the right to development governance for Africa' (2019) 19 African Human Rights Law Journal 365-394 http://dx.doi.org/10.17159/1996-2096/2019/v19n1a18

\title{
Systems problem and a pragmatic insight into the right to development governance for Africa
}

\section{Carol C Ngang*}

Researcher, Free State Centre for Human Rights, University of the Free State, South Africa

https://orcid.org/0000-0001-7222-4693

\section{Summary}

This article draws from a previous publication by the same author and aims to provide an account of the concept of the right to development governance as a rights-based model for development suited to addressing the realities and myriad of development challenges confronting the African continent. In spite of Africa's diverse socio-economic, cultural and geopolitical dynamics, the continent has occupied centre stage in the human rights and development discourse, most often presented in a negative light as the birth place of conflicts and instability, disease, extreme levels of poverty, endemic corruption, democratic insufficiencies, governance malpractices and general decline in an otherwise prosperous world. While efforts to speed up transformation have over the years multiplied at various levels, Africa is reported to be making very slow progress in meeting development goals. The situation necessitates the question: What is the problem? In responding to this question, the article achieves a threefold purpose. First, it demonstrates that the development challenges with which Africa is confronted are a systems problem requiring a rightsbased solution in the form of a context-specific model to accelerate improved standards of living and the attainment of human well-being in larger freedom. Second, it illustrates that Africa is retarded in development because of the lack of an adequate model to deliver on the promise to ensure improved living standards for the peoples of the continent. Third, it

LLB (Yaoundé) IDHA (Fordham) SUSTLAW (Antwerp) LLM LLD (Pretoria); NgangCC@ufs.ac.za. This article is a revised version of a paper presented at the 2nd International Conference on the Right to Development that took place at the Centre for Human Rights, University of Pretoria, South Africa, in August 2018. I am grateful to the conference participants for the helpful feedback and also to the anonymous reviewers for their instructive comments. 
explores the practical dimensions of the right to development governance as a functional model with the potential to ensure the collective advancement of Africa, which guarantees to impoverished peoples an entitlement to socio-economic and cultural development.

Key words: systems problem; neo-legalism; governance malpractices; democratic deficits; right to development governance; human rights and development; Africa

\section{Introduction}

In a previous article I make the argument for conceptualising the right to development governance as a home-grown rights-based development model suited to addressing the realities and the myriad of development challenges confronting the African continent. ${ }^{1}$ Under 'right to development governance' I mean a pragmatic model which is central to framing the political and socio-economic and cultural systems to ensure improved living standards in Africa. The conceptualisation of this model draws from a range of binding and non-binding instruments, which all envisage that socio-economic and cultural development can and, in fact, ought to be achieved. ${ }^{2}$ Added to this is the need for a functional development model, which should enable Africa to advance in the area of improved well-being for the people much more than it is today.

Notwithstanding Africa's diverse socio-economic, cultural and geopolitical dynamics, which suggest a huge potential for development,

1 See CC Ngang 'Towards a right to development governance in Africa' (2018) 17 Journal of Human Rights 107.

2 Art 22 African Charter on Human and Peoples' Rights, adopted in Nairobi, Kenya, on 27 June 1981; art 10 African Youth Charter, adopted in Banjul, The Gambia, on 2 July 2006; art 19 Protocol to the African Charter on Human and Peoples' Rights on the Rights of Women in Africa, adopted in Maputo, Mozambique, on 11 July 2003; Preamble African Charter on Democracy, Elections and Governance, adopted in Addis Ababa, Ethiopia, on 30 January 2007; Constitution of the Republic of Cameroon 1972 and amended Preamble, read together with art 65; art 58 Constitution of the Democratic Republic of Congo (DRC) 1996; art 43 Constitution of the Federal Republic of Ethiopia 1994; art 7 Constitution of the Republic of Benin 1990; art 30 Constitution of the Republic of Malawi 1994; Transforming our world: The 2030 Agenda for Sustainable Development Resolution A/RES/70/1 adopted by the UN General Assembly on 27 September 2015, para 10; paras 11 \& 24 UN Millennium Declaration Resolution A/55/L.2 adopted by the UN General Assembly on 8 September 2000; Rio Declaration on Environment and Development adopted at the UN Conference on Environment and Development, Rio de Janeiro, 3-14 June 1992, Principle 3; para I(10) Vienna Declaration and Programme of Action adopted by the UN World Conference on Human Rights UN Doc A/CONF.157/24, 25 June 1993; para 42 Report of the Meeting of Experts of the First Ministerial Conference on Human Rights in Africa, Kigali, Rwanda, 5-6 May 2003 EXP/CONF/HRA/RPT(II); para 2 Grand Bay Declaration and Plan of Action adopted by the First OAU Ministerial Conference on Human Rights held in Grand Bay, Mauritius, April 1999; para 6 Solemn Declaration on Gender Equality in Africa adopted by the AU Assembly of Heads of State and Government in Addis Ababa, Ethiopia, July 2004. 
the continent has often been presented in a negative light as the least developed region in the world; a birth place of conflicts and instability, disease, extreme levels of poverty, endemic corruption and insensible leadership resulting in democratic insufficiencies, governance malpractices and general decline, which together describe unacceptably low standards of living. While development intervention efforts have over the years multiplied and Africa is reported to have experienced unprecedented economic growth, living standards have not improved for the large majority of the African peoples and, thus, progress in meeting human development targets remains a major problem. ${ }^{3}$ Ten of the world's 13 poorest and least developed countries are in Africa. ${ }^{4}$

So, what is the problem in or with Africa? In over half of a century after independence, why is Africa unable to sustain appropriate processes to ensure improved living standards for its peoples? These questions are posed with the understanding that without stating the actual problem that Africa is confronted with, it would be difficult to craft appropriate remedies to address the replicating challenges mentioned above. In the face of these challenges, the last decade has experienced an increasing shift towards rights-based approaches, including the right to development, in dealing with them. With regard to the entitlement guaranteed to the peoples of Africa to aspire for development as a human right, further questions that need exploring are: What does the right to development aim to achieve? What determines progress towards making the right to development a reality in Africa?

In phrasing a response to these questions, I aim to illustrate that the development challenges with which Africa is confronted essentially are of a human rights nature - more exactly, a denial of the right to development - necessitating a remedy mechanism that responds directly to that problem. The theory of cause and effect (causality), which governs the relations between events, ${ }^{5}$ explains that a denial of the right to development would invariably result in the kind of development challenges, characterised by low standards of living that is common in almost all of Africa. A sustainable remedy would require looking not at the effect but at the cause of the problem, implying an unlikeliness that a remedy of a different nature would be appropriate in redressing Africa's development setbacks or that a functional

3 K Beegle et al Poverty in a rising Africa (2016) xi-xii; S Sako \& G Ogiogio 'Africa: Major development challenges and their capacity-building dimensions' (2002) The African Capacity Building Foundation - Occasional Paper 1 3-4; AJ Ali 'The right to development in Ethiopia' in E Brems, C van der Beken \& SA Yimer (eds) Human rights and development: Legal perspectives from and for Ethiopia (2015) 70; R Kiely 'The crisis of development' in R Kiely \& P Marflect (eds) Globalisation and the Third World (1998) 24.

4 PJ Magnarella 'Achieving human rights in Africa: The challenge for the new millennium' (2000) 4 African Studies Quarterly 18.

5 ND Goodman 'Learning a theory of causality' (2010) MIT, Department of Brain and Cognitive Sciences - Pre-print 2. 
solution could be found by pursuing overtly unrelated approaches to development.

To elucidate on this argument, I proceed in part 2 to define Africa's development challenges as a systems problem that disallows the realisation of the right to development. Meanwhile, as explained in part 3, the right to development necessitates an enabling environment, which requires looking at the outcomes factor as well as the procedural measures to ensure its realisation. In part 4 I provide an analysis of the right to development governance as a mechanism for gauging development in Africa or by which the standard of living could be measured. In conclusion, I reiterate the argument that unless Africa recognises that it is confronted by a human rights problem necessitating the right to development governance model as a remedy mechanism, aspirations for better living conditions will remain unattainable.

\section{Systems problem that disallows the right to development}

\subsection{Deviation from the capability and self-determination standards}

The history of Africa, dating back to the periods of colonialism, has been characterised by conventional systems that primarily only promote paternalism, subjugation, structural inequalities, exclusion and deprivation. The emergence of the human rights movement in the mid-twentieth century triggered the need for systemic changes, on account of which liberation from colonial rule was achieved on the basis of the right to self-determination. Self-determination entitles the peoples of Africa to freely make political choices and to pursue socioeconomic and cultural development in accordance with the policies they have freely chosen. ${ }^{6}$ The entitlement to self-determination is corroborated by the guarantee of sovereign ownership over natural wealth and resources, which should be disposed of only in the interests of the African peoples who, it is stated, may under no circumstance be deprived of their wealth and resources. ${ }^{7}$

Although other factors might have contributed to the decolonisation project, at the core of the African liberation struggles was the fact that the colonised peoples were exploited, dehumanised, abused and denied basic rights and freedoms. Decolonisation then meant that a new system would be established through which these ills would be corrected. It also meant by all reasonable calculation that

6 Common Article 1(1) of the International Covenant on Civil and Political Rights and the International Covenant on Economic, Social and Cultural Rights, Resolution 2200A (XXI) adopted by the UN General Assembly in December 1966; art 20(1) African Charter.

7 Common Article 1(2) of ICCPR and ICESCR; art 21(1) African Charter. 
the systems that sustained the abuse of human rights and the denial of basic freedoms would be abolished. On account of the right to selfdetermination, which is known to embody the right to development, the peoples of Africa are granted the liberty to adopt a governance model to ensure genuine freedoms and to formulate policies suitable for ensuring that socio-economic and cultural development is achieved. Particularly requisite of such policies is the need to regulate the wanton exploitation of the continent's resources.

As pointed out in the introductory part, the recorded setbacks to development in Africa, which translate into very low standards of living, suggest that the prevailing status quo remains one of programmed poverty. This, as I argue, is sustained by inherited or borrowed models that have no bearing on addressing the range of development challenges, and by home-grown models which rather compromise the realisation of the right to development. Granted that poverty is a violation of human rights, ${ }^{8}$ it follows that the peoples of Africa are not by nature created to be poor. They are impoverished rendered poor - by political design through the systems that strip them of the intrinsic entitlements that are supposed to guarantee equality of opportunity for development and also of the basic freedoms to aspire for better standards of living. Poverty limits the articulation of creative potentials and, thus, robs the African peoples of the resilience and the coping capacity to escape poverty.

The right to development in Africa is conceptualised with recognition of the potential to self-sustain and to self-govern which,

8 D Brand et al 'Poverty as injustice' (2013) 16 Law, Democracy and Development 273-275; FDoz Costa 'Poverty and human rights from rhetoric to legal obligations: A critical account of conceptual frameworks' (2008) 5 SUR International Journal on Human Rights 86-88; MF Prada Empowering poor through human rights litigation (2011) 7; T Campbell 'Poverty as a violation of human rights: Inhumanity or injustice?' (2003) CAPPE - Working Paper 2003/9 1-19; T Pogge (ed) Freedom from poverty as a human right: Who owes what to the very poor? (2008) 2-11; Statement by former UN High Commissioner for Human Rights, Mary Robinson (1997-2002) quoted in United Nations Development Programme 'Poverty reduction and human rights: A practice note' http:// www.undp.org/poverty/practicenotes/povertyreduction-humanrights0603.pdf (accessed 24 July 2018), (noting: 'I am often asked what is the most serious form of human rights violations in the world today, and my reply is consistent: extreme poverty'); Statement by former UN Secretary General, Kofi Anan, quoted in UN Office of the High Commissioner for Human Rights 'Human Rights in Development' http://www.unhchr.ch/development/poverty-Ol.html (accessed 24 July 2018) (stating: 'Whenever we lift one soul from a life of poverty, we are defending human rights. And whenever we fail in this mission, we are failing human rights'); Statement by former UN Higher Commissioner for Human Rights, Navi Pillay; quoted in '25th Anniversary of the Declaration on the Right to Development' www.un.org/en/events/righttodevelopment/ (accessed 24 July 2018) (pointing out that '[i]t's not an act of nature that leaves more than one billion people around the world locked in the jaws of poverty. It's a result of the denial of their fundamental human right to development.') 
according to capability theorists, ought not to be limited if humancentred development is to be achieved. ${ }^{9}$ The capability theory builds on the need to expand opportunities and choices and, consequently, to advance the capacity of the African peoples to freely set their own development priorities. To this end, Sen's conception of development as freedom implies that the systems that shape development processes ought to allow for expansion of the human capability to function, the liberty to explore opportunities within the often constrained socio-economic and political space, and the agency to define acceptable standards for sustained livelihood. ${ }^{10}$

As the basis for the realisation of human rights, capabilities are recognised as inborn entitlements representing the dignity and worth of the human person in aiming at the highest attainable standard of living in larger freedom from fear and from want, which within the African context is rather constrained by political determinants and socio-economic factors. The capability approach which, according to Fudaka-Parr, centres on the 'primacy of people; their well-being as the purpose of development and their agency as an essential element of the development process', 'offers a coherent philosophical framework for thinking about the full range of development challenges, starting with the question of how development should be defined' ${ }^{11}$

Necessitating free expression, the capabilities approach embodied in the right to self-determination and also in the right to development is supposed to shape not only the narrative but, importantly, also the policy framework for development in Africa. With the understanding that the underlining purpose of development is to improve human well-being, the African development agenda ought to be defined by the right to development standard as emphasised in the Preamble and in article 22 of the African Charter on Human and Peoples' Rights (African Charter). The right to development literally translates from the African Charter as an integrated process for equalising opportunities for the advancement of all peoples to participate in and to enjoy the benefits obtaining from socio-economic and cultural development. ${ }^{12}$ Contrary to the many different interpretations, the African conception of the right to development acknowledges the collective potential of all the peoples of Africa to participate in the development process without restraint and to be able to determine a

9 M Nussbaum Creating capabilities: The human development approach (2011) 1718; A Sen Development as freedom (1999) 3-11 87-95; A Sen 'Development as capability expansion' in S Fudaka-Parr \& AK Shiva Kumar (eds) Readings in human development: Concepts, measures and policies for a development paradigm (2003) 6-11.

10 Sen (1999) (n 9) 87-95.

11 S Fudaka-Parr 'Theory and policy in international development: Human development and capability approach and the Millennium Development Goals' (2011) 13 International Studies Review 123.

12 See H Armiwulan 'Development and human rights' (2008) China Human Rights 32. 
policy agenda that allows for fairness and the equitable distribution of development gains. ${ }^{13}$

It should be emphasised that the right to self-determination and, of course, the right to development are primarily collective in nature, engendering the opportunity to exercise the functioning to selfsustain and to self-govern and, in consequence, to explore the alternative to define development in a transformative manner as aiming to achieve broad-scale improved well-being as a central priority. This has been the optimism of the peoples of Africa which, however, over time has gradually dissipated. Pent-up expectations for greater freedoms, improved capabilities and expanded opportunities for better living standards have had to compete with capitalist policies that require aspirations for human well-being to cede to economic demands that have predominated the development agenda and define it primarily in fiscal and growth terms.

Although the framework for development in Africa recognises that there is a right to development, the disconnect between the theoretical guarantees of that right and the mechanism for its realisation is apparent in the overt pursuit of capitalistic approaches when its realisation requires more of a socialist orientation. ${ }^{14}$ The African conception of a human right to development is embedded in socialist thought. Proponents of African socialism hold the view that to liberate the continent from historical injustices requires broad-based transformation, equal opportunities for development, egalitarian patterns of redistribution, equitable access to the resources to ensure a net improvement in living standards and an emphasis on the worth of the human person as the primary drivers of development rather than as tools to be used to achieve economic growth targets. ${ }^{15}$

13 For contrary interpretations of the right to development, see $\mathrm{K}$ de Feyter 'Towards a framework convention on the right to development' (2013) Friedrich Ebert Stiftung 17; ME Salomon 'Legal cosmopolitanism and the normative contribution of the right to development' in SP Marks (ed) Implementing the right to development: The role of international law (2008) 17; A Sengupta 'Development cooperation and the right to development' (2003) Copyright (c) 2003 Arjun Sengupta 20; A Sengupta 'On the theory and practice of the right to development' (2002) 24 Human Rights Quarterly 880 (proposing the right to development to be achieved through development cooperation which, however, basically takes away the right of participation and ownership of the development process from the African peoples).

14 MA Lebowitz 'The path to human development: Capitalism or socialism?' (2009) 60 Monthly Review https://monthlyreview.org/2009/02/01/the-path-to-humandevelopment-capitalism-or-socialism/ (accessed 20 March 2019).

15 E Akyeampong 'African socialism, or the search for an indigenous model of economic development?' (2017) Harvard University - African economic history Working Paper Series 36/2017 1-18; K Nkrumah 'African socialism revisited' in Peace and Socialism Publishers Africa: Nationalism and social revolution (1967) 4; P Rich 'African communalism' (1976) The Black Sash 14-15. 
Without discounting the important role that economic growth plays in achieving development, as some scholars have highlighted, ${ }^{16}$ the right to development is contravened when development policies are designed to focus only on achieving growth statistics. This is evident across Africa where development is measured principally in terms of growth rates, a measure by which a number of countries demonstrate significant levels of economic achievement. ${ }^{17}$ Contrasted with the United Nations Development Programme (UNDP) classification for the same countries, most African countries with high growth rates fall within the lowest ranking on the human development index. ${ }^{18}$ For example, Equatorial Guinea, which in spite of an impressive double digit economic growth rate of 23,6 per cent, only ranks at the 141 st position in human development. ${ }^{19}$

The pursuit of economic growth impedes development by stripping the poor of inherent entitlements, subjugating them to want and misery and portraying them as not deserving of the opportunities that are supposed to avail to all peoples as envisaged by the right to development. This is closely linked to the globalisation agenda which, in spite of its insufficiencies, has become the framework that shapes and defines development in Africa, as I proceed to explain.

\subsection{Neo-legalism and the global development agenda}

The acquisition of independence from colonial rule created the expectation that a new dispensation would be established for Africa, to be sustained through socio-economic and cultural development. While this expectation failed to be realised, it became obvious to the peoples of Africa only some 20 years later that the nominal independence (devoid of socio-economic and cultural selfdetermination) obtained in the $1960 \mathrm{~s}$ was not translating into improved standards of living. It then necessitated the adoption of the African Charter with an endorsed undertaking to prioritise the right to socio-economic and cultural development. Even so, making the right

16 S Kamga \& S Heleba 'Can economic growth translate into access to rights? Challenges faced by institutions in South Africa in ensuring that growth leads to better living standards' (2012) 9 SUR - International Journal on Human Rights 82; A Sengupta et al 'The right to development and human rights in development: A background paper' (2004) The Norwegian Centre for Human Rights - Research Notes 07/2004 6-8; A Sengupta 'The human right to development' (2004) 32 Oxford Development Studies 184-185.

17 S Radelet 'Emerging Africa: How 17 countries are leading the way' Centre for Global Development Brief (September 2010) https://www.cgdev.org/sites/default/ files/archive/doc/full_text/EmergingAfrica/Radelet_EmergingAfrica.html (accessed 3 April 2019). The following ten countries are indicated to have some of the most impressive economic growth rates in Africa: Ethiopia 4,1 per cent; Mozambique 5,3 per cent; Sudan 4,7 per cent; Uganda 3,8 per cent; Rwanda 3,7 per cent; Chad 3,4 per cent; Tanzania 3,0 per cent; Burkina Faso and Sierra Leone 2,8 per cent; Mali 2,5 per cent; Lesotho and Nigeria 2,3 per cent.

18 United Nations Development Programme 'Human development reports: 2018 statistical update' United Nations Development Programme http://hdr.undp.org/ en/2018-update (accessed 3 April 2019).

19 See Radelet (n 17) \& UNDP (n 18). 
to development a reality has remained a major challenge not only because of a lack of the commitment to do so but, as I argue, because of acquiescence to a 'neo-legalism' that practically disallows the realisation of the right to development.

Under neo-legalism I understand the post-colonial global framework where despite admittance into the United Nations (UN) system, developing countries are systematically denied recognition as equal sovereign subjects of international law, which in the main only applies to protect developed countries. ${ }^{20}$ Neo-legalism is by nature aligned to the concepts of neo-colonialism and neo-liberalism which, in combination, undermine the quest by developing countries for global balance and, therefore, also dilutes the international law principle of sovereign equality. It deprives developing countries of the right to assert a legitimate entitlement to higher standards of living and conditions of socio-economic and cultural advancement on the basis of equal rights and self-determination as guaranteed in article 55 of the UN Charter.

Neo-legalism applies, for example, in the context of global trade and the climate change crisis. Even though Africa has largely not been involved in formulating the global trade rules (crafted principally by developed countries) or in generating the climate change crisis (as much as industrialised countries do), it is obligated to comply with the established global norms in these domains. Neo-legalism operates on the indeterminate principle that without sufficient economic clout, developing countries do not qualify to influence global decision making. Consequently, Africa has remained excluded from geopolitics and representation in major international decision-making fora and processes where universal standards and the barometers for measuring those standards are set and required to apply uniformly.

The idea of clustering into a global compact where human rights and problems of a socio-economic and cultural as well as humanitarian nature could be redressed in a concerted manner as stated in articles 55 and 56 of the UN Charter, creates hope for equitability in the attainment of higher standards of living for all peoples around the world. However, because of the inability to assert the right to sovereign equality, the very essence of adhering to universal norms robs developing countries of the potential to measure up equally with developed countries in terms of aspiring for higher standards of living. ${ }^{21}$

20 CC Ngang 'Differentiated responsibility under international law and the right to development paradigm for developing countries' (2017) 11 Human Rights and International Legal Discourse 287; A Anghie Imperialism, sovereignty and the making of international law (2005) 52; E Kwakwa 'Emerging international development law and traditional international law: Congruent or cleavage?' (1987) 17 Georgia Journal of International and Comparative Law 453.

21 See F Kirchmeier 'The right to development: Where do we stand? State of the debate on the right to development' (2006) Friedrich Ebert Stiftung - Occasional Paper 2312. 
Poverty remains a daunting setback to global development which in accordance with the provisions of the UN Charter demands a concerted international response as a legal obligation. ${ }^{22}$ However, as Mahalu observes, the UN has instead espoused the practice of allocating to 'almost all instruments related to development a rather ambiguous legal character', which only prescribes moral norms that states may or may not comply with. ${ }^{23}$ The neo-legalism that obtains from this arrangement thus allows the pursuit of the global development agenda predominantly through soft law in the form of resolutions and declarations intended to insulate developed countries of legal responsibility in redressing the historical wrongs committed against developing countries or in dealing with poverty and related development challenges. ${ }^{24}$

It may be argued that the UN is not a world government and, therefore, has no legitimacy to impose its will on a sovereign state. According to my argument this is where the systems problem actually originates. The UN was created to accomplish a triple mission to secure global peace and security, to ensure universal adherence to human rights standards, and to promote global development. It also provides an operational framework for the articulation of contemporary international law. As regards global peace and security, the UN has always found justification to enforce its will, especially when the interests of developed countries (the makers of global policies) are at stake. However, relating to human rights and development, which constitute the primary concern of developing countries, the approach has generally been more pacific, characterised by compromises as was demonstrated with the adoption of the Declaration on the Right to Development (RTD Declaration). Despite the recognition in the 1993 Vienna Declaration that the right to development is a human right similar to every other human right that is legally recognised under international human rights law, the Declaration has remained soft law.

The politics of economic globalisation and dominance of the market economy that fuels the practice of neo-legalism allows developed countries, because of the authority they exert, to set the agenda and the pace for global development, provide the funding and, of course, determine the rules ('conditionalities') for compliance and the manner of implementation. Accordingly, developing countries are earmarked for targeted development interventions within the framework of development assistance and, thus, charged

22 See arts $55 \& 56$ of the UN Charter 1945.

23 CR Mahalu 'Human rights and development: An African perspective' (2009) 1 Leiden Journal of International Law 19.

24 See generally Thomas Pogge's works on poverty: T Pogge 'The Sustainable Development Goals: Brilliant propaganda? (2015) Annals of the University of Bucharest - Political Science Series ISSN 1582-2486 1-15; TW Pogge 'Severe poverty as human rights violation' (2003) UNESCO Poverty Project 1-38; T Pogge 'Real world justice' (2005) 9 The Journal of Ethics 29; T Pogge 'World poverty and human rights' (2005) 19 Ethics and International Affairs 1-7. 
simply with implementation and reporting back in accordance with imposed donor conditionalities with which recipient countries must comply. In seeking to satisfy donor conditionalities, African governments have generally been misled into setting their priorities wrongly by focusing on issues relating to political governance and democratisation, while the circumstances on the ground demanded that more attention be directed towards socio-economic and cultural development necessary for developing the productive capabilities of the peoples of Africa.

The obviously biased global system that disallows developing countries from defining development in their own terms triggered the campaign for a new international economic order (NIEO), which was pioneered mostly by African countries in anticipation of rupturing the status quo of global imbalances and development injustices. ${ }^{25}$ However, the NIEO campaign failed on account of the lack of sufficient economic leverage by developing countries to influence the politics that inform global governance. The RTD Declaration evolved from this background with the emphasis on development cooperation as a means to enable developing countries to attain comprehensive levels of development and to eliminate obstacles that may hinder the development process. 26

The compromises that informed the adoption of the RTD Declaration were born out of the fear that the legal recognition of the right to development would compel developed countries to remedy the damages inflicted on developing countries. Kirchmeier describes the fears nursed by developed countries in the sense that the legal recognition of the right to development would empower developing countries to make legitimate demands which developed countries would be constrained to fulfil. ${ }^{27}$ Denying legal recognition of the right to development basically implies depriving Africa and other developing countries of the entitlement to assert socio-economic and cultural self-determination against the pressures exerted by developed countries under the banner of development cooperation.

Unlike the framework for cooperation under the UN Charter that envisages 'respect for the principle of equal rights and selfdetermination', the non-binding cooperation framework provided by the RTD Declaration has taken precedence as the basis for extraterritoriality in the provision of development assistance as a means to achieve the right to development. ${ }^{28}$ Shue explains that

$25 \mathrm{R}$ Adeola 'The right to development under the African Charter: Is there an extraterritorial reach?' in CC Ngang, S Kamga \& V Gumede (eds) Perspectives on the right to development (2018) 36.

26 Declaration on the Right to Development adopted by General Assembly Resolution 41/128, 4 December 1986, arts 3(3) \& 4(2).

27 Kirchmeier (n 21) 11-12.

28 O de Schutter et al 'Commentary to the Maastricht Principles on Extraterritorial Obligations of States in the Area of Economic, Social and Cultural Rights' (2012) 34 Human Rights Quarterly 1084; G Ooms \& R Hammonds 'Global 
'where the state with the primary duty to protect rights fails - for lack of will or capacity - to fulfil its duty, some other agent ... must step in and provide the missing protection'. ${ }^{29}$ This is conceived mainly from the viewpoint that developing countries need help, entailing the provision of development assistance to satisfy that need. ${ }^{30}$ However, Pogge contends that an effective remedy is not to be found in charitybased assistance but rather in the duty to redress the harm inflicted on the poor through the unjust global system. ${ }^{31}$ On the contrary, the perpetrators of these injustices have remained reticent about a legal obligation to repair the damages that their actions cause to the impoverished. ${ }^{32}$

Although non-state actors, particularly extractive industry multinationals, are involved in extensive projects that impact negatively on the livelihood of local peoples, the neo-legalism practically insulates them from accountability for wrongful actions. A case in point is the abusive exploitation of crude oil by Shell Corporation in the Niger Delta region of Nigeria, resulting in massive oil spills that cause severe environmental damage that adversely affects the local population. ${ }^{33}$ However, in making a case in this regard in the SERAC litigation, legal action could not be brought against Shell under the African Charter because as a basic principle of international law, non-state actors are not bound by treaties to which they are not party.

It requires the Nigerian government as well as other state governments in Africa to take appropriate measures to regulate the activities of the multinational corporations and non-state actors operating within their territories, which unfortunately they have largely failed to do. Notwithstanding the fact that multinational corporations are increasingly required to comply with human rights standards in their operations, as yet there is no legally enforceable

constitutionalism, responsibility to protect, and extra-territorial obligations to realise the right to health: Time to overcome the double standard (once again)' (2014) 13 International Journal for Equity in Health 2-4; Maastricht Principles on Extraterritorial Obligations of States in the area of Economic, Social and Cultural Rights adopted by the International Commission of Jurists, 28 September 2011, paras 1-44; SI Skogly 'Extra-national obligations towards economic and social rights' (2002) International Council on Human Rights Policy 1.

29 H Shue Basic rights: Subsistence, affluence, and US foreign policy (1996) 176-177.

30 Sengupta (2002) (n 13) 880; De Feyter (n 13) 17; Salomon (n 13) 17; Sengupta (2003) (n 13) 20; L Siitonen 'Political theories of development cooperation: A study of theories of international cooperation' (1990) UN University WIDER 15-16; K Arts \& A Tamo 'The right to development in international law: New momentum thirty years down the line?' (2016) 63 Netherlands International Law Review 239-242; J Hausermann 'A human rights approach to development: Some practical implications for WaterAid's work' (1999) Rights and Humanity 5.

31 Pogge (2005) (n 23) 35.

32 OO Oduwole 'International law and the right to development: A pragmatic approach for Africa' (2014) International Institute of Social Studies 8; Kirchmeier (n 21) 11.

33 Social and Economic Rights Action Centre (SERAC) \& Another v Nigeria (2001) AHRLR 60 (ACHPR 2001) (SERAC). 
mechanism to guarantee realisation. Uvin observes that multinational corporations often only employ the human rights narrative to gain moral high ground and the legitimacy to 'redefine the conditions of misery and exploitation for the rest of the world'. ${ }^{34}$

Contrary to the rights-based standards that envisage the simultaneous realisation of development and human rights, the neolegalism prioritises the growth of the market economy more than the observance of human rights. Economic growth, of course, is inevitable for development but its realisation in isolation does not guarantee that improved living standards will be achieved for all peoples. Thus, in contrast to impressive economic growth rates, empirical evidence holds that living standards in Africa have regressed. The situation is exacerbated by the fact that African governments have failed to take seriously the right to development enshrined in article 22 of the African Charter.

In the absence of a robust policy framework or the leverage to explore the development space, the peoples of Africa are constrained to conform to the forged normalcy of dependency, domination and the wanton exploitation of the African heritage. If improved living standards are to be achieved and sustained in Africa, the context posits the need to reaffirm the right to development as a model for governance and people-centred development programming. While it necessitates a drastic shift from the neo-legalism that portrays Africa's development challenges as a global problem but does not provide contextually relevant remedies, the governance and democratic practices in Africa make the systems problem even more compounded, as I proceed to explain.

\subsection{Democratic deficits and governance malpractices}

When the Organisation of African Unity (OAU) was established in 1963 , one of its core founding purposes was '[t]o co-ordinate and intensify efforts their cooperation and efforts to achieve a better life for the peoples of Africa'. ${ }^{35}$ It required and apparently still requires responsive leadership and a functional system to ensure the attainment of this purpose. However, as Appiagyei-Atua rightly intimates, the system in place has rather been one of 'bumps on the road $^{\prime 36}$ resulting from a string of deficits and malpractices that have progressively defined the kind of unorthodox political culture that Africa is known for. These deficits and malpractices are documented in the repertoire of relevant literature and do not necessitate recounting here. Because the role of the state (represented by a legitimate

34 P Uvin 'On high moral ground: The incorporation of human rights by the development enterprise' (2002) 17 The Fletcher Journal of Development Studies 8.

35 Charter of the Organisation of African Unity adopted in Addis Ababa, Ethiopia, on 25 May 1963, art 2(1)(b).

36 K Appiagyei-Atua 'Bumps on the road: A critique of how Africa got to NEPAD' (2006) 6 African Human Rights Law Journal 524. 
government) is central to achieving the right to development, I highlight the issue of unconstitutional changes of government to illustrate how it breeds anarchical leadership and corruption, which combine in a systemic manner to frustrate the processes for development, which should normally result in a better life for the peoples of Africa.

As part of the endeavour to ensure that an improved standard of living is guaranteed to the peoples of Africa, a range of regional and domestic legal instruments and institutional mechanisms have increasingly prescribed the norms that should lay the framework for the exercise of the rule of law, sane democracy, efficient governance, the observance of human rights and the realisation of the right to development. To be more proactive, unconstitutional changes of government are identified as road bumps that slow down the processes for development in Africa, necessitating additional practical measures by way of laying down the general rules on governance and the conduct of democratic elections as a means to remedy the situation. ${ }^{37}$

The Preamble to the African Charter on Democracy, Elections and Governance (African Democracy Charter), for instance, highlights the commitment 'to promote the universal values and principles of democracy, good governance, human rights and the right to development'. It presupposes that if these values and principles are adhered to, improved living standards would be attained. Accordingly, Udombana makes the case for considering democratic governance not only as a guiding principle but in essence as a human right, particularly relevant for Africa. ${ }^{38}$ Unfortunately, Africa has continued to be threatened by systemic disruptions that go quite contrary to the established standards for democratic governance and, by inference, contrary to the guarantees on the right to development.

It is reported that there have been at least 200 coups d'état across Africa since the $1960 \mathrm{~s},{ }^{39}$ not excluding the recent theatrical yet graceful removal of the recalcitrant ailing Robert Mugabe from power in Zimbabwe in 2017. Besides the forceful and often violent take-over of power by the use of military force, Africa has repeatedly experienced a sequence of palace coups where incumbent heads of state have robbed their contenders (and hence the electorate) of legitimate victory at elections and, thus, retained power unconstitutionally. Because unconstitutional changes of government contravene the law, it is logical to argue that it renders the legitimacy of the government that takes over power illegally null and void and,

37 See African Charter on Democracy, Elections and Governance (n 2); Lomé Declaration, adopted by the OAU Assembly of Heads of State and Government in Lomé, Togo, July 2002; Declaration on the Principles Governing Democratic Elections in Africa adopted in Durban, South Africa, July 2002.

38 NJ Udombana 'Articulating the right to democratic governance in Africa' (2003) 24 Michigan Journal of International Law 1223.

39 Aljazeera 'Inside story' Aljazeera News, 18 September 2015. 
consequently, dispossesses the government that does so of legal recognition.

The 2000 Declaration for an OAU Response to Unconstitutional Changes of Government (Lomé Declaration) underscores the fact that governments that accede to power through unconstitutional means will not be 'recognised by the OAU [AU]' and would be 'suspended from participating in the policy organs of the OAU [AU]'. Controversially, governments in Africa that have come to power or retained power through unconstitutional means have not only gone on to rule for several years (often beyond constitutionally stipulated mandates) but have also been fully integrated within the structures of the African Union (AU) and its policy organs. It remains unclear and questionable how and at what point these unlawful governments eventually gained legitimacy. Although the Lomé Declaration does not impose any legally-binding obligation because of its soft law status as a declaration, it is worth making reference to, in order to question the effectiveness of the processes to establish legitimate governance and a functional system for development in Africa.

Unconstitutional changes of government (by military force or through the ballot box) have been a recurrence in Africa to the point that the few countries that have not recorded such an experience make up the exception more than the rule. It creates conditions of instability that disrupts the development process. In contravention of the norms that forbid unconstitutional changes of government, these governments have more often than not eventually gained recognition (under conditions of legalism rather than legality or legitimacy) which, in turn, provides a breeding space for the kind of repressive political leadership and deep-rooted corruption that have impacted adversely on the extent to which the right to development is envisaged to be achieved. The right to development imposes an obligation to create an enabling environment to facilitate its realisation, to which I now turn.

\section{Enabling environment for development}

An enabling environment for development in the context of this article represents both an imaginary and a realistic space within which states are required to create favourable conditions to ensure that the right to development is achieved without constraint. ${ }^{40}$

\subsection{Outcomes factor}

In very lucid terms, development ought essentially to be defined by what it aims to achieve which, within the rights-based framework, entails improving living standards for all peoples. It requires looking at the outcome factor which, drawing from article 22(1) of the African 
Charter, is qualified by the legal promise to all the peoples of Africa to have the equal opportunity to enjoy the right to socio-economic and cultural development. It is worth reiterating that the emphasis on socio-economic and cultural development is intended to ensure that an improved living standard is achieved in an inclusive manner. Further to this assurance, to reap equitable benefits from the development process, the freedom and identity of the African peoples must be situated at the core of governance and development planning.

This conceptual framing of the right to development is of strategic importance in shaping development thinking in Africa which, in contrast to the stipulation in the Preamble to the Africa Charter, wrongly prioritises civil liberties, political freedoms and the reform of democratic processes as the basis for creating development. Reports on the human rights situation in Africa frequently point out abuses relating mostly to civil and political rights, which for the most part only portray Africa as failing in democratic governance. There is very little reporting on violations of socio-economic and cultural rights and the right to development. While it is worth acknowledging that unresponsive leadership and democratic deficits have become the bane to development on the continent, the right to development illustrates that the peoples of Africa are confronted more with insufficiencies in socio-economic and cultural development than with the need for sensible politics and the reform of governance processes.

While political development may be relevant for the achievement of the right to development, it is not inherent to human well-being and, therefore, its absence may not necessarily devalue the right to development. It adds no substantial value to human well-being if, for instance, democratic reforms render the political processes flawless and free of malpractices, and also guarantee the full range of fundamental human rights (to life, to vote, to enjoy a fair trial, and so forth), civil liberties and political freedoms (of expression, of movement, and so forth). On the flipside, however, impoverished peoples are unable to afford the most basic necessities such as education, food, water, shelter and primary health care for daily survival and livelihood sustainability, or are deprived of the cultural practices that define them as a people. The failure to achieve desirable levels of well-being in Africa could be attributed to the fact that governance and development on the continent are defined and overly shaped by politics and the exercise of state power, which supersedes and trumps aspirations for socio-economic and cultural development and the well-being of the African peoples.

On the contrary, when populations are sufficiently empowered socio-economically and culturally, their free, active and meaningful participation in politics would be spontaneous and productive. This is definitely what the drafters of the African Charter had in mind when they explained in the Preamble that it is only when socio-economic and cultural development has been achieved that the enjoyment of 
civil and political rights can effectively be guaranteed. Because the right to development in Africa is couched in legal terms with imposed obligations to respect, to protect and to fulfil, it provides the means for ensuring that the rule of law is applied, that justice is established to protect the impoverished from deprivation, exploitation and related development injustices, and that aspirations for improved well-being are attained.

The right to development governance is situated within this context as a framework model to define the modalities for state action in advancing socio-economic and cultural development, and to set the standards for holding the state to legitimate accountability. As a protective mechanism, as Kunanayakam notes, it guarantees that peoples are not treated as objects to be utilised to achieve development objectives but as the central subject or the primary focal point around which development should revolve. ${ }^{41}$ Gawanas further explains that to put people at the centre of the development process means to invest in their capabilities and to expand their preferences for better living standards. ${ }^{42}$

When Doudou Thiam and Cardinal Etienne Duval pioneered the call in the late 1960s for a proclamation of the right to development, they were in principle advocating a development praxis defined by the goal to achieve optimal improvement of living standards for the impoverished peoples of Africa. ${ }^{43}$ Kéba M'baye's seminal article in 1972 further articulates the view that development entitles every person to better living standards as a matter of human rights. ${ }^{44}$ As the commissioned Chairperson of the Committee of Experts who drafted the African Charter, M'baye's perception of improved living standards for the peoples of Africa as the end goal of development, greatly informed the formulation of the African conception of the right to development as enshrined in the African Charter.

The emphasis on all peoples as stated in article 22(1) is justified by the reasoning that living standards need to be equalised across the continent. Of course, this aspiration is unrealistic in an Africa where prevailing situations demonstrate that development gains do not directly translate into better living conditions. This provokes nervewracking questions in relation to the endless pursuit of futile policies, which over the years have failed to produce tangible results. Having

41 T Kunanayakam 'Report of the Working Group on the Right to Development on its 14th session' (2013) Human Rights Council A/HRC/24/37 4-5; RTD Declaration (n 26) art 2(1).

42 B Gawanas 'The African Union: Concepts and implementation mechanisms relating to human rights' in A Bosl \& J Diescho (eds) Human rights in Africa: Legal perspectives on their protection and promotion (2009) 145.

43 See Ngang (n 1) 111-112; F Ouguergouz The African Charter on Human and Peoples' Rights: A comprehensive agenda for human dignity and sustainable democracy in Africa (2003) 298.

44 K M'baye 'Le droit au développement comme un droit de l'homme: Leçon inaugural de la troisième session d'enseignement de I'Institut International des Droits de l'Homme' (1972) 5 Revue des Droits de l'Homme 505. 
identified the outcome factor as the requisite first step in ensuring the effective implementation of the right to development, the proceeding action entails exploring the procedural measures for creating peoplecentred development in Africa.

\subsection{Procedural measures}

A comprehensive understanding of the standard laid down in the Preamble and in article 22 of the African Charter is instrumental in determining the process for creating development, understood as aiming to achieve improved living standards. Besides imposing the traditional duty for realisation on states, article 22 also ascribes a corresponding duty on all the peoples of Africa to exercise the right to development. The liberty to exercise the right to socio-economic and cultural development gives the African peoples the responsibility to take tangible action in developing their capabilities to ensure that they contribute productively to development with due regard to their 'freedom and identity'. ${ }^{45}$ By this, the African Charter recognises the potential of the African peoples to make independent and informed development choices.

The Charter enjoins state parties to ensure that the development space is free of constraints and allows the opportunity for the right to development to be achieved. ${ }^{46}$ This is predetermined by the fact that the outcome factor informs the development process while the development process in turn justifies the outcome. 47 If the process is wrongly conceived, it is unlikely that the anticipated outcome of better living standards would be achieved. In this light the right to development is portrayed as the right to a comprehensive process that is envisaged to translate into substantive guarantees of genuine freedoms, self-determination and the capacity to make policy choices for the collective benefit of the African peoples. Related to this are three interrelated procedural measures that are central to the realisation of the right to development.

The first of these procedural measures, deduced from the radical promise to all the peoples of Africa, requires their broad-based involvement in the development process and, accordingly, imposes an obligation to ensure that participation not only is conducive but also gainful to the African peoples in terms of improved living standards. Popular and meaningful participation guarantees that crafting

45 Art 22(1) African Charter.

46 OC Okafor "'Righting" the right to development: A socio-legal analysis of article 22 of the African Charter on Human and Peoples' Rights' in SP Marks (ed) Implementing the right to development: The role of international law (2008) 60; A Mmari 'The challenges surrounding the implementation of the right to development in the African Charter on Human and Peoples' Rights in light of the Endorois case' LLM dissertation, University of Pretoria, 2012 23; Kirchmeier (n 21) 11; art 22(2) African Charter.

47 W Rodney How Europe underdeveloped Africa (1973) 1; Sengupta (2004) (n 16) 183-184; Sengupta (2002) (n 13) 848-852. 
solutions to Africa's development challenges must involve the peoples of Africa which, however, has not always been the case. Owing to the perception of Africa as a target for development intervention, its development master plans have generally been conceptualised by foreign stakeholders, while the peoples of Africa are only required to comply with implementation in accordance with prescribed conditionalities.

The structural adjustment programmes, for instance, were exclusively an IMF/World Bank initiative, crafted with the assumption, as Dicklitch and Howard-Hassmann argue, that it was intended to release the productive capacity of the African peoples and thus stimulate economic growth, without which socio-economic rights would not be achieved. ${ }^{48}$ Even though the Millennium Development Goals (MDGs) were envisaged to respond to Africa's development woes, including especially the goal to reduce poverty by half, it is not unknown that the MDGs were conceived and drawn up in 'relative casualness' in the basement of the UN office in New York by a small team of UN officials led by Lord Mark Malloch-Brown. ${ }^{49}$ The implementation of the MDGs in Africa would probably have been much more successful if their formulation involved context-specific remedies to the issues that are particular to the African continent.

Participation entitles the peoples of Africa to be seen not as objects of charity or victims of development deserving to be helped, but as proactive development actors with the potential to shape the processes that impact adversely on their lives. Malloch-Brown's confession of how '[t]he development of the MDGs was a bit like nuclear fusion' begs the question of how and to what extent the global agenda incorporated African concerns into that fusion other than to earmark Africa simply as destined to receive development assistance. With the acknowledgment that development is situational and people-driven, participation anchors on the extent to which freedoms and the expansion of capabilities are guaranteed to engineer transformation in Africa.

While global initiatives have not provided an adequate framework for the realisation of socio-economic and cultural development, homegrown frameworks such as the New Economic Partnership for Africa's Development (NEPAD) and the Lagos Plan of Action have either also failed or lack the appropriateness to sustain the hopes of the peoples

48 S Dicklitch \& R Howard-Hassmann 'Public policy and economic rights in Ghana and Uganda' in S Hertel \& L Minkler (eds) Economic rights: Conceptual, measurement, and policy issues (2007) 325-327.

49 M Tran 'Mark Malloch-Brown: Developing the MDGs was a bit like nuclear fusion' The Guardian https://www.theguardian.com/global-development/2012/nov/16/ mark-malloch-brown-mdgs-nuclear (accessed 22 August 2018). Malloch-Brown has confessed that ' $[t]$ he development of the MDGs was a bit like nuclear fusion', combining a 'human-rights based approach embodied in the Human Development Report; a World Bank pro-market structural adjustment strategy; and the target-setting mindset of rich donors in the Development Assistance Committee of the Organisation for Economic Co-operation and Development'. 
of Africa. The current 2063 Agenda for Development provides reasons to be optimistic, but as long as the donor-recipient relationship between the $\mathrm{AU}$ and its funding partners, such as the European Union (EU) and China, is not decisively ruptured, the realisation of the right to development would remain far-fetched.

Contrary to the more expanded understanding of participation as entailing the active and meaningful involvement of the peoples in decision making, contribution to and sharing equitably in the benefits deriving from the development process, participation in Africa still is largely conceived primarily in terms of representation where the involvement of the population (electorate) is only measured and esteemed to be legitimate by the regularity of their votes in the ballot box. While representative democracy is crucial for creating development, it has rather mostly bred 'powerful' politicians in Africa, whose contribution to the development process predominantly has been counter-productive to the aspiration for improved living standards for the impoverished populations.

The second important procedural measure for the realisation of the right to development is the obligation to adopt adequate national development policies which, in order to respond relevantly to the need for improved living standards, must be capable of addressing the socio-economic and cultural realities that impact adversely on livelihood in Africa. On a broad scale, the policy framework should aim at the constant improvement in human well-being, on the basis of their active, free and meaningful participation and in the equitable distribution of the benefits resulting from the development process. 50 This requirement translates into a specific legal duty to adopt relevant 'legislative and other measures', without which the entitlement to socio-economic and cultural development would not be achieved. ${ }^{51}$

Interestingly, unlike with socio-economic and cultural rights, the right to development does not subscribe to the principle of progressive realisation on the basis of resource availability. Its realisation is contingent on the taking of policy measures, which must be accomplished immediately in assurance that the process for improved living standards could then be sustained. In addition to article 22, the provision on self-determination in the African Charter guarantees that the peoples of Africa 'shall freely determine their political status and shall pursue their economic and social development according to the policy they have freely chosen' ${ }^{52}$

In spite of these assurances, there is reason to be worried about the persistent pursuit of policies that manifestly contravene the right to development in Africa. While there has been an increase in development interventions and policy measures intended to ameliorate living conditions in Africa, Arbour observes that what is

50 Art 2(3) RTD Declaration.

51 Art 22 African Charter, read together with art 1.

52 Art 20(1) African Charter. 
essential is not the quantity of policy decisions that are taken, but the tangible contribution of those policy decisions to improving the livelihood circumstances of the impoverished peoples whose rights are constantly denied. ${ }^{53}$ For Kennedy, development policy formulation entails making choices among policy alternatives with the aim to achieve optimal development outcomes and to ensure equitable redistribution and balanced development. ${ }^{54}$

If this thinking is to apply to Africa, the national development policy frameworks ought to show evidence of choice between peoplecentred development and the pursuit of economic growth, essentially because poverty constitutes a major development challenge in Africa much more than the need to advance the market economy. While economic growth is instrumental for development, poverty eradication presents a more urgent priority and, therefore, needs to inform the policy choices for Africa. Accordingly, national development plans are expected to demonstrate greater commitment to getting rid of poverty. On the contrary, the development plans of most African countries tend to focus on misplaced policy choices. The South African 2030 National Development Plan, for example, portends to focus on building human capabilities and in expanding opportunities as a means to eradicate poverty and to curb inequality in the country. ${ }^{55}$ However, the 429-page document tilts more towards nation building and growing the economy and only summarily makes reference to people's participation in the development process on the last page. ${ }^{56}$

Lastly, an enabling environment for development requires extensive resource mobilisation, in accordance with which the African Charter sets obligatory standards. State parties are duty-bound to comply with these standards to ensure that socio-economic and cultural development is achieved with due regard to the equal enjoyment of the African common heritage. Read together with article 21(5), the Charter obligates state parties 'to undertake to eliminate all forms of foreign economic exploitation particularly that practised by international monopolies so as to enable their peoples to fully benefit from the advantages derived from their national resources' ${ }^{57}$ By this commitment state parties are enjoined to sustainably manage and redistribute the continent's resources to the benefit of the peoples of

53 UNOHCHR 'Statement by Ms Louise Arbour, United Nations High Commissioner for Human Rights on the opening of the 61 st session of the Commission on Human Rights (Geneva 14 March 2005)' http://newsarchive.ohchr.org/EN/ NewsEvents/Pages/DisplayNews.aspx?NewsID=2799\&LangID=E (accessed 21 May 2018).

54 D Kennedy 'The rule of law as development' in J Hatchard \& A Perry-Kessaris (eds) Law and development: Facing complexities in the 21st century: Essays in honour of Peter Slinn (2003) 18-19 26.

55 National Planning Commission National Development Plan: Vision for 2030 (2011); see the Foreword by Minister Trevor Manuel.

56 National Planning Commission (n 55) 429.

57 Art 21(5) African Charter. 
Africa. Controversially, most African governments, in contravention of this provision, have rather colluded with foreign multinationals to plunder the resources to which the peoples of Africa are entitled.

On account of the continent's resource potential, the peoples of Africa are entitled to enjoy the highest attainable standard of living. In reality, they have over the decades suffered deteriorating standards as a result of dispossession and the wanton and abusive exploitation of those resources; in most cases by foreign multinationals, but also by African governments or a complicity of both, as in the case of the Nigerian government's collusion with Shell Petroleum in the abusive exploitation of crude oil within the Ogoni community in the Niger Delta. ${ }^{58}$ Many other local and indigenous communities in Africa, including the Endorois and the Ogiek in Kenya, have been forced to surrender their ancestral lands for the benefit of a governmental project (a game reserve), with the attendant impact on the well-being of the affected peoples. 59 The quest for land redistribution in South Africa clearly articulates a similar problem. Despite the constitutional promise to improve the quality of life and to free the potential of every citizen, access to and ownership of land has remained the exclusive preserve of a small (mostly white) fraction of the population, amounting to a denial of equality of opportunity for development for the over 80 per cent of the black population.

It is crucial to admit that the implementation of the right to development in Africa has remained constrained owing to a combination of convoluted factors. These factors include governance problems that breed endemic corruption, the very low levels of development in many African countries as well as the attendant global competition for economic growth. The policy framework of most African countries thus tend to prioritise the pursuit of economic growth, which is mischaracterised to represent development with the understanding that human rights would be looked into after economic growth has been achieved.

The capitalist dispensation that evolves from the pursuit of economic growth (justified by the need for the accumulation of more and more wealth in the hands of individuals) then provides the foundation for Africa's political economy where it is legitimate for public functionaries and politicians to loot state treasuries and appropriate national wealth with impunity. It also provides the rationale for the new Africa where, contrary to the spirit of communalism, it becomes acceptable for Africans with more political connections or economic clout to deprive other Africans, especially the poor and less privileged, of their entitlement to the common

58 SERAC case (n 33).

59 See eg Centre for Minority Rights Development \& Others v Kenya (2009) AHRLR 75 (ACHPR 2009) paras 269-298; African Commission on Human and Peoples' Rights (Ogiek Community v Republic of Kenya (2017) Appl 6/2012 paras 201-217; see also CC Ngang 'Indigenous peoples' right to sustainable development and the green economy agenda' (2015) 44 Africa Insight 31-46. 
heritage. This compounds the systems problem that I have alluded to earlier, which disallows the right to development and, thus, shortcircuits the legal obligation that enjoins state governments to ensure improved well-being and better living standards for all the peoples of Africa.

\section{Right to development governance barometer}

\subsection{Functional dimensions}

The right to development governance is formulated as a functional model that combines and emphasises the rule of law, and the African conception of human rights with the emphasis on socio-economic and cultural development as an assurance of the collective advancement of the African peoples. Collective advancement, as a central tenet of the right to development governance, represents the idea that the peoples of Africa should be able to define development in their own terms, with due consideration of the existing diversities and consequently guarantee equality of opportunities, meaningful participation as well as equitable redistribution of available resources and the benefits resulting from the development process.

It involves the duty to eradicate tendencies of domination that impoverish and strip the African peoples of the capabilities to shape their own development future, ${ }^{60}$ to consolidate the gains of political independence and accelerate the quest for socio-economic and cultural emancipation, ${ }^{61}$ and to redress the effects of the globalisation that impacts adversely on living standards in Africa. ${ }^{62}$ Agenda 2063 recognises that since 1963 the future of the continent has largely been inspired by the spirit of pan-Africanism, a focus on decolonisation and 'development based on self-reliance and selfdetermination ... and people-centred governance' ${ }^{63}$ To flout these prerequisites means that the right to development will not be achieved, justifying its functional dimension as a rights-based model for engineering socio-economic and cultural self-determination and a benchmark for legitimate accountability. ${ }^{64}$

60 J Eckel 'Human rights and decolonisation: New perspectives and open questions' (2010) Essay-Reviews 111.

61 Preamble Constitutive Act of the African Union adopted in Lomé, Togo, on 11 July 2000.

62 Hausermann (n 30) 20.

63 African Union Commission 'Agenda 2063: The Africa we want' (2015) African Union para 19.

64 Ngang (n 1) 107-122; P Oyugi 'The right to development in Africa: Lessons from China' in CC Ngang, SD Kamga \& V Gumede (eds) Perspectives on the right to development (2018) 284; Ngang (2017) (n 19) 278-280; UN Human rights Realising the right to development: Essays in commemoration of the 25th anniversary of the Declaration on the Right to Development (2013) 495; WP Nagan 'The right to development: Importance of human and social capital as human rights issues' (2013) 1 Cadmus Journal 30; SP Marks 'The human rights framework for 
Noting that the right to development presents the opportunity to define the tangible dimensions of 'development' in Africa with respect to the peoples' primary concerns as 'they strive to break out of poverty and underdevelopment', ${ }^{65}$ Uvin contends that ' $[\mathrm{t}]$ here is no politically grounded analysis of what stands in the way of his approach'. ${ }^{66}$ Drawing from its African origins and the rationale behind its formulation, there is no justification why the right to development is not being considered as the key instrument for regulating peoplecentred development practice on the continent. As a framework model established by law, the right to development incorporates the duty to craft development policies that respond to the African peoples' aspirations for socio-economic and cultural selfdetermination. ${ }^{67}$

The right to development governance is conceived to guide consistency in policy formulation, development programming and implementation decision making and, therefore, should direct the manner in which Africa is governed and also shape thought patterns and actions with regard to the roles and contributions that the peoples of Africa owe as a responsibility in setting the basis for gauging living standards on the continent. For the most part it necessitates the advancement of human productive capabilities, guarantees of genuine freedoms and liberties in exploring opportunities to development and setting a minimum threshold for determining the attainment of collective well-being for all the peoples of Africa.

The right to development governance requires African governments to be focused more on domestic policy making and development programming oriented towards addressing the socioeconomic and cultural needs of the African peoples than seeking to achieve global targets or donor conditionalities that are predominantly defined by the politics of global dominance. The rapidly-growing presence of China in Africa, for instance, has been the subject of mixed reaction and controversy among the peoples of Africa. While China denies its 'invasion' of Africa as neo-colonialism, Sun explains that China is more interested in its own political aggrandisement, economic gains and diplomatic ambition for global dominance than in mutual benefits through the south-south cooperation that it purports to promote. ${ }^{68}$

development: Seven approaches' (2003) François-Xavier Bagnoud Centre for Health and Human Rights 12; NJ Udombana 'The Third World and the right to development: Agenda for the next millennium' (2000) 22 Human Rights Quarterly 769-770; Sen (n 9) 187 147-148.

65 Oduwole (n 32) 4.

66 Uvin (n 34) 8.

67 Arts 1, 20(1), 21(1) \& 22(2) African Charter; art 2(3) RTD Declaration.

68 Y Sun 'Africa in China's foreign policy' (2014) John L Thornton China Centre and Africa Growth Initiative 1-2. 


\subsection{Context-related capabilities}

Development in Africa does not need to trail behind contemporary forms of industrialisation and modernisation. I have earlier advanced the argument that with historical evidence of ancient African civilisations, advancement on the continent needs to be defined by the extent to which the peoples of Africa can produce, innovate and invent, based first and foremost on the immediate needs and the local resource potential marketable consumables. In line with the socioeconomic and cultural needs and the resources available to meet those needs, technology and industrialisation in Africa are likely to take an exclusive dimension, which is supposed to then determine the specific capabilities to be developed in conformity with the aspiration contained in Agenda 2063 to forge a uniquely African model for development and transformation. ${ }^{69}$

Although Agenda 2063 underscores the fact that in order to achieve transformation, the African population needs to be sufficiently empowered, instead of seeking ways to develop the relevant capabilities, for some unexplained reason African policy makers believe in and, thus, emphasise the need for technology transfer as a means to engineer development on the continent. ${ }^{70}$ While technology transfer has repeatedly been emphasised in different international instruments as a means to support the efforts of developing countries for advancement, ${ }^{71}$ it is inconceivable that industrialised countries would genuinely commit to transfer the technologies (for which in most instances they enjoy a monopoly) to developing countries. Doing so would mean ceding exclusive intellectual property rights over their inventions or products, something that is extremely unlikely to happen. Stemming from this is the crucial indictment to ensure that the training and educational systems in Africa are restructured to produce not only a literate population but a versatile and productive people with the capabilities to engineer the kind of transformation that is relevant for the continent.

\subsection{Liberties and freedoms}

The UNDP articulates the fact that human development is incomplete without basic freedoms, a reality that has throughout history characterised liberation struggles. ${ }^{72}$ Poverty and underdevelopment are historical phenomena, deeply rooted in extensive dispossession and denial of the liberty to assert the right to socio-economic and cultural development. The right to development is framed within the

69 Paras 74(e) \& (h) African Union Commission (n 63).

70 See African Union Commission (n 63) paras 52-58 in contrast to para 72(0).

71 S Amin Imperialism and unequal development (1977) 169; see also United Nations Compendium of international arrangements on transfer of technology: Selected instruments (2001).

72 UNDP Human development report 1990 (1990) 16. 
universal standard reading of human rights as those birth rights that arise out of inborn aspirations for basic freedoms and a life worth living with dignity, respect and protection, without which the African person cannot enjoy the quality of life that they have reason to value. $^{73}$ Contrary to the perception of freedoms and liberties as relating only to civil and political rights, to sustain living standards of the dimension envisaged by the right to development is achievable only to the extent that genuine liberties and freedoms in asserting socio-economic and cultural self-determination are guaranteed to all the peoples of Africa.

It is worth reiterating that the right to development grants the opportunity to make development choices, which includes the freedom to reject systems that do not work for Africa. While the UNDP identifies literacy as a key indicator for measuring living standards, in as much as the liberty to choose between alternative educational systems remains constrained, scoring high on literacy would comply with ticking the box for that indicator but with minimal practical benefit to Africa. Between 2015 and 2016, as part of the nationwide campaign for free university education in South Africa, students' grievances included demands for a decolonisation of the higher education curriculum as a means to ensure that learning is tailored to respond to local realities and the developmental priorities of the country. Unfortunately, the student protests were brutally suppressed and their legitimate demands for free, quality and decolonised education jettisoned by the South African government, which interestingly is mandated to ensure that the right to education enshrined in article 29 of the Constitutions is fulfilled.

\subsection{Minimum threshold for collective well-being}

The African conception of the right to development necessitates setting a minimum threshold for determining collective well-being through legitimate guarantees of equality of opportunity for socioeconomic and cultural development to all the peoples of Africa. ${ }^{74}$ According to Sengupta, countries can develop in many different ways, but if these various ways by which development takes place do not guarantee equality of opportunity, then it violates the right to development. 75 The universal entitlement to the highest attainable standard of living lends credence to the fact that it is essential to standardise living conditions across the world by virtue of the fact that

73 See J Mubangizi 'Towards a new approach to the classification of human rights with specific reference to the African context' (2004) 4 African Human Rights Law Journal 94.

74 See SP Marks 'Obligations to implement the right to development: Political, legal and philosophical rationales' in BA Andreassen \& SP Marks (eds) Development as a human right: Legal, political and economic dimensions (2006) 59-60; A Sengupta 'Realising the right to development' (2000) 31 Development and Change 848.

Sengupta (n 74) 848. 
whatever the context, development ultimately aims at the attainment of human well-being.

However, owing to the unique characteristics that differentiate the peoples of Africa and to ensure that they do not fall through the cracks of the global system, it is difficult to endeavour to define the standard threshold for livelihood by applying a uniform measuring instrument. Such a determination can only be made in relation to specific contexts, which incontestably is a function of the value systems (culture) that define the lifestyle of different peoples around the world. A recognition of the distinctiveness of the African identity and value systems, thus, is central to determining the minimum threshold for their collective well-being. Because matters relating to community value systems, lifestyle and well-being can only be defined by the peoples involved, I contend that universally-accepted indicators for gauging development (economic growth rate and the human development index) do not convincingly equate to improved living standards and, therefore, add no concrete value to the living conditions of the peoples of Africa.

The economic growth measurement for development focuses primarily on advancing the market economy while the UNDP barometer simply portrays the extent of global imbalances by which Africa has consistently ranked lowest on the human development index compliance listing. ${ }^{76}$ It is worth noting that in spite of reported remarkable improvements in human development, 77 no African country has since 1990 risen above the 63rd ranking occupied by Seychelles. In 2010 Libya ranked 67th but, following the military assault by NATO in 2011, has regressed to 102 nd position in the most recent classification. To elucidate on the argument that the human development criteria do not necessarily add value to living standards, I make reference to the literacy and income indices to illustrate the limitations of their application in the African context.

Literacy levels are reported to be increasingly high across Africa, ${ }^{78}$ suggesting that acquiring knowledge in terms of being able to read and write and to graduate from school with a qualification is not an issue. However, with regard to the contribution of education to development, the contrasting levels of underemployment, the lack of access to opportunities because of inaccurate skills, resulting in the importation of both soft and hard skills; services, technology, machinery and even basic consumables, demonstrates that literacy does not equate to productivity and, hence, does not translate into

76 AfDB, OECD, UNDP, ECA 'Human development in Africa' in AfDB, OECD, UNDP, ECA Africa economic outlook (2013) 73-88.

77 See eg Africa economic outlook (2017) 101-109.

78 Literacy levels in the following African countries are estimated as follows: Seychelles, Equatorial Guinea and South Africa, 95 percent; São Tomé and Principe, 92 per cent; Libya, Namibia and Mauritius, 91 per cent; Gabon, 89 per cent; Cape Verde and Botswana, 88 per cent; Burundi, Swaziland and Zimbabwe, 87 per cent. 
development. African governments has largely failed to transform the education systems inherited at independence, ${ }^{79}$ to ensure that they respond appropriately to the development priorities on the continent. For instance, although the export of primary products (raw materials) is known to be a major constraining factor to development in Africa, the education system is yet to be designed to produce the skills and technology required to transform these primary products into consumable exportable goods.

The income index by which poverty and underdevelopment are measured by the US $\$ 1,5$ per day baseline is erroneously intended to be applied universally despite the fact that not every society defines well-being in monetary terms. The US $\$ 1,5$ measurement would apply in a capitalist context where the dollar determines purchasing power and, hence, is conveniently used as a measuring instrument to determine living standards. In Africa, large sections of the population do not operate within a capitalist market economy where wealth is measured per head count, but rather within a communal system where wealth is predominantly a shared possession, which the African Charter recognises as a 'common heritage'. ${ }^{80}$ Applying the income index in this context, therefore, is unlikely to provide an accurate measurement of living standards.

Going by the income benchmark in gauging development explains why over the years many African countries have consistently been ranked as extremely poor, heavily indebted, and least developed. Only lately have some of these countries reluctantly been considered as emerging economies. In most local communities in Africa, wealth, especially land and the natural resources found thereon, are collectively owned by the entire community and not by specific individuals. Development in this context can only be determined in function of the collective entitlement to the material things that guarantee well-being to all the members of the community. By implication, the income measurement constrains the extent to which appropriate remedies could be crafted to eradicate poverty and to remedy Africa's development challenges.

The exigency to eradicate and to remedy the range of other development challenges translates into a duty to ensure the full realisation of the right to development. Undeniably, while much of Africa's past has been shaped by external pressures, the present and the future remain a determination that only the peoples of Africa can make on the basis of an entrenched right to development, which by virtue of its legal protection by the African Charter imposes an absolute obligation that compels Africa to define its own standards for

79 K Nkrumah Africa must unite (1963) xiii. Nkrumah observed that the colonial education systems were designed to sustain colonialism and to promote imperial ideologies with no concrete bearing on local realities except to create 'much ignorance and few skills'. 
development. Unfortunately, for the reasons that have been explained in this article, African governments have fared poorly in satisfying the duty to make the right to development practically relevant in redressing the day-to-day livelihood experiences of their impoverished peoples.

\section{Conclusion}

In the face of multiplied efforts to accelerate development in Africa, it is worth reiterating that without recognition of the fact that the peoples of Africa are collectively confronted with a human rights problem, notably a denial of the right to development, endeavours to improve living standards on the continent will remain beyond reach. While the right to development has evolved in Africa since the late 1960s, essentially as a paradigm originally conceived to redress human rights abuses and development injustices, its practical implementation has for no justified reason been disregarded and its intended purpose thwarted and distorted. Consequently, the way development is understood and practised creates problems, with which the peoples are largely ill-equipped to deal because of the constraints that limit access to opportunities and the incapability to assert entitlement to socio-economic and cultural self-determination.

The argument advanced in the article is to the effect that Africa is legally obligated and, indeed, has the potential to deal with the compelling state of socio-economic and cultural challenges that constrain living standards on the continent. As indicated in article 5 of the RTD Declaration, in order to achieve and sustain improved standards of living, decisive measures need to be taken to eliminate obstacles to development. Unfortunately, these obstacles are generated and sustained by the deep-rooted systems that define and regulate how the peoples of Africa are conditioned to operate in ways that alienate them from the realities on the ground. It requires reformulating the governance system by creating a functional model that sets the minimum threshold for collective well-being.

A denial of the right to development, which is identified in the article as the cardinal problem that robs the peoples of Africa of better living standards, cannot be remedied by a lesser standard that limits entitlement to socio-economic and cultural self-determination. These forms of self-determination lie at the core of the duty to adopt a governance and development praxis that is uniquely African. The cultural component of the right to development in Africa requires promoting a distinctive cultural identity with its associated value systems, which should not be mistaken to connote primitivity, nativism or backwardness, but should rather be seen as a means of asserting exclusive self-determination. This, in essence, is the substance of the right to development in respect of which states are granted both the right and the duty to formulate domestic development policies that reflect the aspirations of their peoples. 
Conceived in this light, the right to development governance necessitates not only a reform of existing laws or the ratification of more and more treaties, but a revolutionary transformation of the African thought patterns and functional modalities. Efforts in this regard remain challenged by the inordinate resistance to substitute the malfunctioning systems that limit socio-economic and cultural development and aspirations for better living standards on the continent. The extent to which better conditions and higher standards of living could be achieved and sustained in Africa can only be determined by a firm commitment to giving practical effect to the right to development as a governance model for engineering socioeconomic and cultural development. Without practically asserting the right to development, entailing the peoples of Africa to define development in terms of their inherent aspirations for well-being, the rest of the world would be justified to impose their conception of what development should be for Africa. That is what European colonialism did and what Chinese imperialism currently is doing, with the conscious or unconscious acquiescence of the peoples of Africa. 